\title{
Assessment and Impact of Leachate Generated by the Landfill City in Abidjan on the Quality of Ground Water and Surface Water (M'Badon Bay, Côte d'Ivoire)
}

\author{
Sangaré Naminata1, Kouassi Edith Kwa-Koffi'1, Kouassi Aka Marcel2 ${ }^{2}$, Yao Koffi Marcellin² \\ ${ }^{1}$ Laboratoire de Chimie Physique, Université Félix Houphouët Boigny, Abidjan, Côte d'Ivoire \\ ${ }^{2}$ Centre de Recherches Océanologiques (CRO), Abidjan, Côte d'Ivoire \\ Email: *aka.marcel.kouassi@gmail.com
}

How to cite this paper: Naminata, S., Kwa-Koffi, K.E., Marcel, K.A. and Marcellin, Y.K. (2018) Assessment and Impact of Leachate Generated by the Landfill City in Abidjan on the Quality of Ground Water and Surface Water (M'Badon Bay, Côte d'Ivoire). Journal of Water Resource and Protection, 10, 145-165.

https://doi.org/10.4236/jwarp.2018.101009

Received: December 8, 2017

Accepted: January 28, 2018

Published: January 31, 2018

Copyright $\odot 2018$ by authors and Scientific Research Publishing Inc. This work is licensed under the Creative Commons Attribution International License (CC BY 4.0).

http://creativecommons.org/licenses/by/4.0/

\begin{abstract}
The municipal Akouedo landfill of the city of Abidjan (Cote d'Ivoire) is composed of more than $60 \%$ of household waste. It lacks a leachate collecting and treatment device. To highlight the impact of the leachate on the receiving environments, some sampling campaigns of leachate, groundwater and surface waters were conducted from June 2013 to January 2014. Analyses of leachate samples revealed relatively high concentrations of trace metals: Fe $(6450 \pm$ $8690 \mu \mathrm{g} / \mathrm{L}), \mathrm{Cu}(400 \pm 272 \mu \mathrm{g} / \mathrm{L}), \mathrm{Zn}(520 \pm 240 \mu \mathrm{g} / \mathrm{L}), \mathrm{Cd}(113 \pm 105 \mu \mathrm{g} / \mathrm{L})$, $\mathrm{Pb}(550 \pm 237 \mu \mathrm{g} / \mathrm{L}), \mathrm{Ni}(312 \pm 97 \mu \mathrm{g} / \mathrm{L})$ and $\mathrm{Co}(77 \pm 56 \mu \mathrm{g} / \mathrm{L})$. Fe is the most abundant chemical element. The analysis of groundwater and surface indicates that the levels of trace metals in these waters are higher than WHO standards except Zn.
\end{abstract}

\section{Keywords}

Leachate, Coastal Lagoon, Groundwater, Trace Metals, Pollution

\section{Introduction}

The disposal of municipal solid waste is a major concern, especially in developing countries where poverty, population growth and high urbanization rates, lack of financial and technical resources can hamper the efficient and sustainable management of waste [1]. Landfill and/or open dumpsite are the common and inexpensive practice for municipal solid waste disposal in developing and developed countries [2]. Unfortunately, the implementation of these "wild" land- 
fills is generally not preceded by an environmental and social impact assessment. As a consequence, they present potential risks to the environment and populations through the emission of biogas and especially the production of leachates.

Leachates composition varies according to several factors such as the nature and the age of the landfill, the type of waste, the method of landfill, the nature of the site and the climatic conditions [3] [4] [5]. Leachates contain dissolved organic and inorganic compounds, trace metals (cadmium, copper, zinc, lead, nickel, cobalt, iron etc.) and xenobiotic organic substances (phthalates, benzene, phenols) [6]-[13]. The mineral fraction of landfill leachates essentially consists of chlorides, sulphates, bicarbonates, potassium, sodium and ammonium, while the organic part is closely related to the age of the waste. If young discharges are characterized by the dominance of volatile fatty acids (especially acetic, propionic and butyric acids), they are predominantly fulvic and humic acids in older leachates [6].

Leachate accumulates at the bottom of the landfill and percolates through the soil leading to the receiving environments (groundwater and surface water) pollution. The impact of leachate on the surface and groundwater has given rise to a number of studies in recent years. The study of the physicochemical quality of groundwater near the Casablanca urban landfill revealed high levels not only of heavy metals but also of trace metals emanating from the leachates [14]. The work of Ikem et al. [10] showed that the sediments of the Ibadan and Lagos (Nigeria) landfills were heavily contaminated by metals such as $\mathrm{Zn}$ and $\mathrm{Pb}$ (Ibadan), and by $\mathrm{Zn}, \mathrm{Pb}, \mathrm{Cu}$ and $\mathrm{Cd}$ (Lagos). Similarly, Kanmani and Gandhimathi [15] reported a case of lead contamination of groundwater near the Aryamangalam landfill in Tamil Nadu (India). Low levels of metal contamination have been reported in the sediments of the landfills Oblogo, Ghana [16] and in the soils of the Enyimba landfill in Nigeria [17].

The metals contained in the leachate can either migrate to the water table and make it unfit for consumption, or accumulate in soils and bioaccumulate in agricultural products [18] [19] [20] [21] [22]. The release of leachate into natural waters can have serious consequences for aquatic species [23]. Sediments are generally considered as a sink for metals and play an important role in the regime of groundwater pollution and aquatic systems [24] [25] [26] [27]. The assessment of metal concentrations in sediment in landfills is essential in understanding the impact of landfill on metal pollution in the environment.

In Côte d'Ivoire, the municipal Akouedo landfill of the city of Abidjan covers an area of over $153 \mathrm{ha}$. The literature only revealed the work undertaken by Adjiri et al. [28] on the chemical and microbial contamination of the soil of the Akouedo landfill and that of Kouassi et al. [29] on the chemical characterization $\left(\mathrm{NO}_{3}^{-}, \mathrm{PO}_{4}{ }^{3-}, \mathrm{NH}_{4}^{+}, \mathrm{DBO}_{5}, \mathrm{DCO}\right)$ of the leachate. The influence of the season on the production of methane released by the landfill Akouédo was also studied by Adjiri et al. [30]. Few other studies have been devoted to the impact of the landfill on the environment in the vicinity of the landfill. The aim of this work is to 
study the impact of the Akouédo landfill leachate on groundwater and the Ebrié lagoon ecosystem.

\section{Materials and Methods}

\subsection{The Study Area}

The study area is the Akouédo landfill, which is the only landfill in the Abidjan district. It is located in the northeast of the district, in the commune of Cocody (residential district high standing), between $396,000 \mathrm{~m}$ and $397,000 \mathrm{~m}$ on the abscissa and between 590,000 $\mathrm{m}$ and 591,000 $\mathrm{m}$ as ordinates in the reference frame UTM 30N. This landfill, established since 1965, covers an area of 153 ha. It is located halfway between the Abidjan-Bingerville axis and $18 \mathrm{~km}$ from the city center. It occupies a talweg with a natural drainage to the Ebrié lagoon (M'Badon Bay), to the south, within $2.1 \mathrm{~km}$ [31]. To the north, it is limited by the high-class residential areas Genie 2000 and Les Lauriers, to the west by the village of Akouédo, and to the east by the village of Akouédo Attié and the commune of Bingerville (Figure 1). In its current functioning, it is classified as a wild dump [32] approximately receiving 550,000 tons of waste per year, of which two thirds are composed of domestic waste and the third remaining of industrial and some dangerous waste [31]. The leachate generated from the landfill is drained in an anarchistic way under the heaps of garbage towards the Bay of M’Badon.

The M'badon bay, one of the Ebrié lagoon ecosystem bays, (Figure 1) is localized between longitude $3^{\circ} 89^{\prime} \mathrm{E}-3^{\circ} 90^{\prime} \mathrm{E}$, latitude $5^{\circ} 34^{\prime} \mathrm{N}$ and altitude $73 \mathrm{~m}$ above the sea level. This bay covers a surface area of $3.91 \mathrm{Km}^{2}$ and has a perimeter of $8 \mathrm{Km}$. It is characterized by depths generally less than $3 \mathrm{~m}$, with a length and average width, respectively of $2.3 \mathrm{~km}$ and $1.70 \mathrm{~km}$. This bay has an estimated water volume $9.8 \times 10^{6} \mathrm{~m}^{3}$. Its watershed is estimated to be 78,000 $\mathrm{Km}^{2}$. The M'Badon bay is under the influence of continental (the Comoe River and rainfall), oceanic and anthropogenic inputs.

\subsection{Water Sampling and Analysis}

Sampling of groundwater, surface waters and leachate was conducted from the leachate flow to the lagoon between 2013 and 2014 during the dry (December and January) and rain seasons (June and July) (Figure 1). Stations L1 and L2 were selected in the valley, $0.3 \mathrm{~km}$ and $0.7 \mathrm{~km}$ respectively from the landfill. The wells located not far from the lagoon and the leachate flow were also sampled (P1 and P2). Eight sampling stations ( $\mathrm{S} 1$ to S8) were also selected in the M'Badon bay, a receptacle of the leachate water. The stations S1, S2, S3 and S6 are near the weir of the leachate. Station S4 is located in a confined area of the bay. Station S5 receives discharges from the population of M'Badon. The S7 and S8 stations are located at the entrance of the bay and receive the waters of the Comoé River during the flood season and the marine waters mainly during the dry season. 


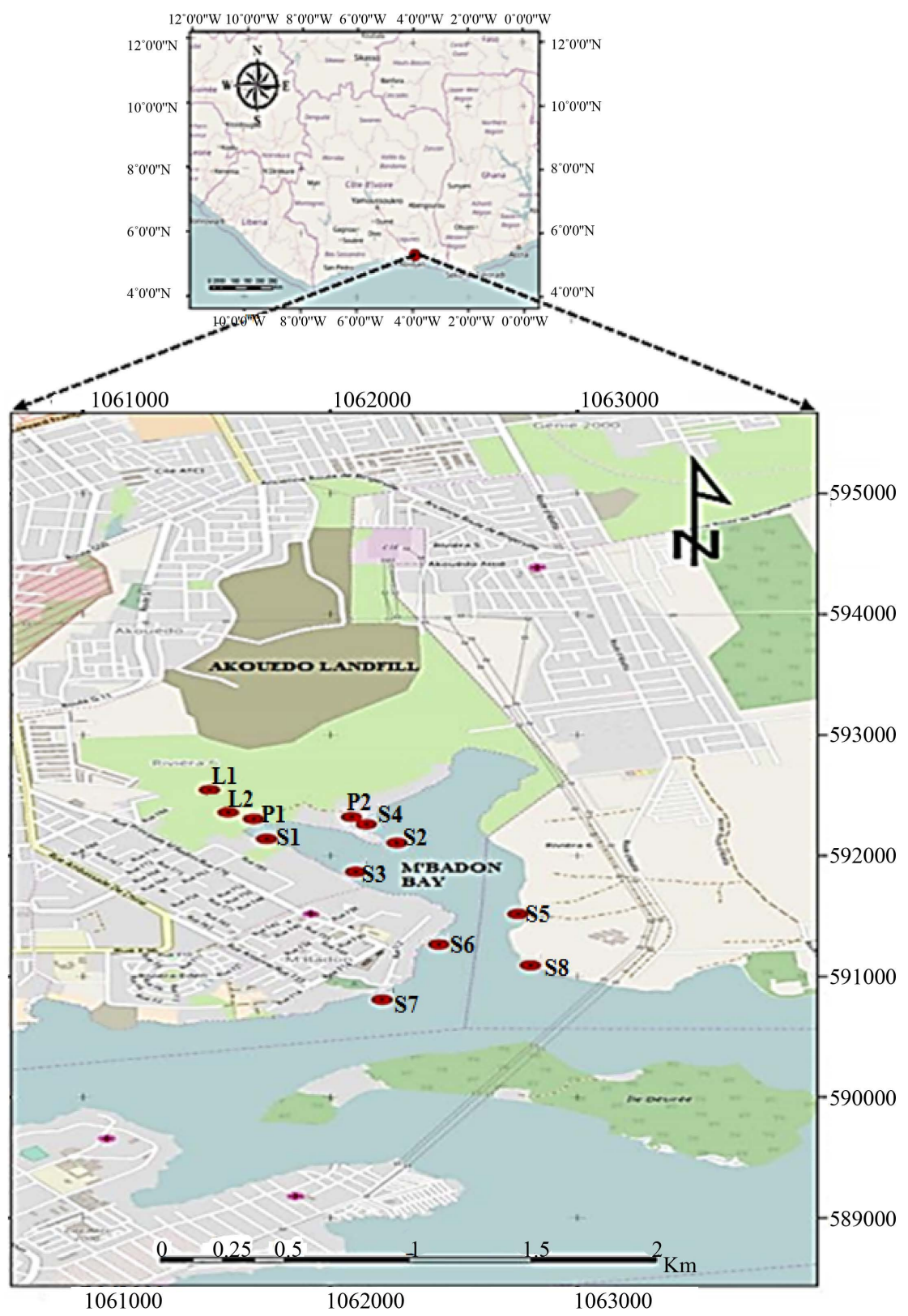

Figure 1. Location of Akouedo landfill and sampling stations.

The water samples were taken using a Niskin bottle at the depth of $0.5 \mathrm{~m}$ and collected in one liter polyethylene bottles. The bottles were stored immediately in $\operatorname{cool}\left(4^{\circ} \mathrm{C}\right)$ and protected from light in order to avoid any possible photo-chemical or biological reaction. In the laboratory, all water samples were directly stored in freezers at temperatures below $4^{\circ} \mathrm{C}$. Temperature, conductivity, salinity and $\mathrm{pH}$ were measured in situ using the $\mathrm{HI} 9828 \mathrm{pH} / \mathrm{ORP} / \mathrm{EC} / \mathrm{DO}$ multiparameter brand HANNA. Trace metals ( $\mathrm{Cd}, \mathrm{Pb}, \mathrm{Cu}, \mathrm{Ni}, \mathrm{Zn}, \mathrm{Fe}$ et $\mathrm{Co}$ ) concentrations were determined using an atomic absorption spectrophotometer to air-acetylene flame like Varian AA20 (SpectrAA100 Varian spectrophotometer, Japan). All water samples for metal analysis were acidified with nitric acid (2\%). For statis- 
tical analysis parametric test of ANOVA (Software Statistica 7.1) and test of WILCOXON were used to compare the mean values of the tested parameters for all the different sampling sites.

\section{Result and Discussion}

\subsection{Leachate Physico-Chemical and Chemical Characterization}

\subsubsection{Leachate Physico-Chemical Characterization}

1) $\mathrm{pH}$

The results of the physico-chemical analyses of leachate samples are presented in Table 1. The $\mathrm{pH}$ in the leachate range from 8.33 to 8.78 (Table 1), with an average of $8.51 \pm 0.14$, showing its basic character. Studies carried out on the same landfill have obtained similar $\mathrm{pH}$ [31] [33]. These data are also of the same order of magnitude as those obtained by El Khamlichi et al. [34] on the landfill in Rabat (Morocco) and Tränkler et al. [35].

The basic character of the leachate seems to indicate that the Akouédo landfill is an old and stabilized landfill, with an anaerobic fermentation (methanogenesis) stage [30]. Leachate waters presenting an acid character are those from the young landfill [36]. The $\mathrm{pH}$ obtained in the leachate from the Akouedo landfill could also be related to the low concentration of volatile organic compounds. Indeed, during acid fermentation, the first phase of anaerobic waste decomposition, young percolates are rich in volatile organic compounds. During this phase, the recorded $\mathrm{pH}$ is generally less than 4 [37]. As leachate ages, it becomes depleted of volatile organic compounds and is enriched with carbonates $\left(\mathrm{CaCO}_{3}\right)$ and ammonium $\left(\mathrm{NH}_{3}{ }^{-}\right)$[5]. This will lead to the increase of the $\mathrm{pH}$ to 7 or higher [38]. The seasonal $\mathrm{pH}$ variation in the leachate (Figure 2) shows that it remains basic in all seasons. It is also important to note that $\mathrm{pH}$ is significantly higher (Wilcoxon test, $\mathrm{p}<0.05$ ) during the rainy season than during the dry season. Our results are corroborated by Er-Raioui et al. [39] who observed a basic leachate with a $\mathrm{pH}$ of 7.87 during the rainy season and acid leachate $(\mathrm{pH}=$ 4.78) during the dry season.

\section{2) Temperature}

The temperature of the leachate varies between $23.90^{\circ} \mathrm{C}$ and $35.19^{\circ} \mathrm{C}$ with an average of $29.52^{\circ} \mathrm{C} \pm 3.12^{\circ} \mathrm{C}$ (Table 1 ). The temperature recorded during the dry season are the highest (ANOVA, $\mathrm{p}<0.05$ ) (Figure 3) and are due to the high ambient temperature. According to Kouamé [31], these temperatures are susceptible to favor the maintenance of colonies of "mesophilic" microorganisms

Table 1. Leachate physical parameters.

\begin{tabular}{ccccc}
\hline Parameters & $\mathrm{pH}$ & Temperature $\left({ }^{\circ} \mathrm{C}\right)$ & $\begin{array}{c}\text { Conductivity } \\
(\mathrm{mS} / \mathrm{Cm})\end{array}$ & Salinity (\%o) \\
\hline L1 & 8.53 & 29.25 & 25931 & 14.97 \\
& $8.33-8.78$ & $23.92-32.2$ & $10060-37990$ & $0.04-23.93$ \\
L2 & 8.50 & 29.79 & 24619 & 13.85 \\
& $8.35-8.71$ & $23.90-35.19$ & $10220-37320$ & $0-23.48$ \\
\hline
\end{tabular}




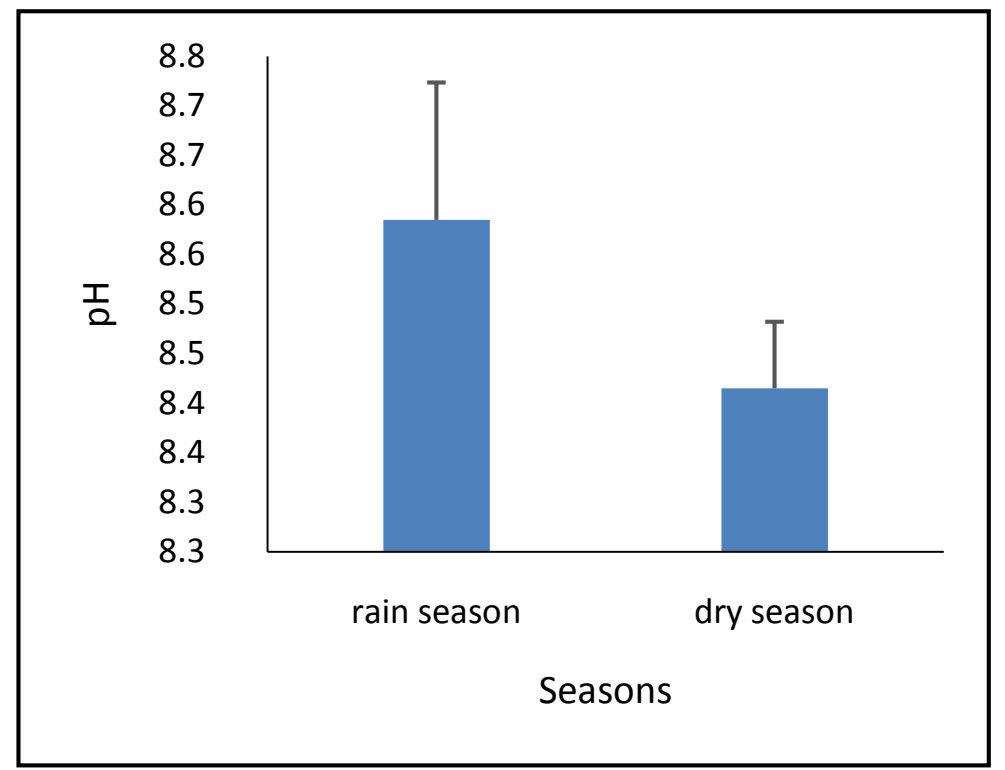

Figure 2. Seasonal variations of $\mathrm{pH}$ in leachate.

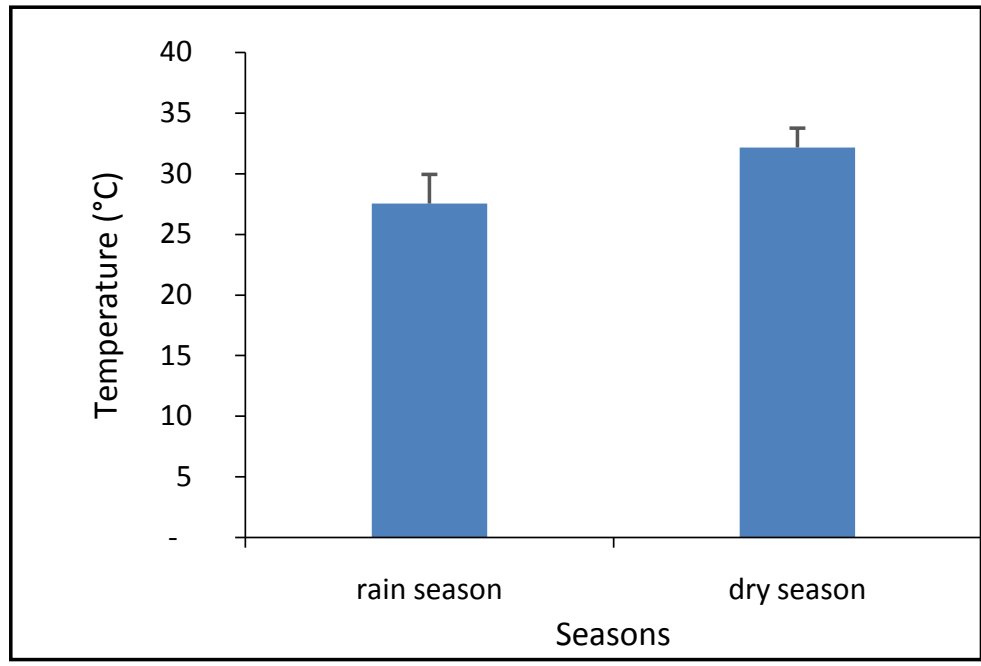

Figure 3. Seasonal variations of temperature in the leachate.

which develop at a temperature between $20^{\circ} \mathrm{C}$ and $40^{\circ} \mathrm{C}$. The increase in temperature can also stimulate the oxidation, the hydrolysis and the remineralization of waste by bacteria (stimulation of bacterial enzymatic activity) and make the leachate rich in mineral elements [31]. Temperatures recorded during the dry season are the highest (ANOVA, $\mathrm{p}<0.05)$ (Figure 3 ) and are due to the high ambient temperature.

\section{3) Conductivity}

The electrical conductivities recorded in leachate fluctuate between 10,060 and $37990 \mu \mathrm{S} \cdot \mathrm{cm}^{-1}$ (Table 1). The mean conductivity is $25,275 \pm 8340.99 \mu \mathrm{S} . \mathrm{cm}^{-1}$. Kouassi et al. [29] studied the physico-chemical characteristics of the Akouedo landfill and obtained conductivities ranging from $2390 \mu \mathrm{S} / \mathrm{cm}$ to $17,150 \mu \mathrm{S} / \mathrm{cm}$; the mean value being $7805.42 \mu \mathrm{S} / \mathrm{cm}$. These results are lower than those obtained 
in this study, but of the same order of magnitude as the conductivity measured in the leachates of the landfills in Colombia [40] and Morocco [41]. The high conductivities are related to a strong accumulation of ions in the Akouedo leachate. High conductivities are recorded during the dry season (Figure 4). The low conductivities obtained during the rainy season could be explained by the dilution phenomenon. Indeed, during this season, the leachates receive a large quantity of water resulting in a considerable dilution of the chemical elements [31].

\subsubsection{Chemical Characterization of Leachate}

\section{1) Total metallic trace elements concentration in the leachate}

Trace metals from the Akouédo landfill leachate have average concentrations of $6450 \pm 8690 \mu \mathrm{g} / \mathrm{L}$ for Fe, $400 \pm 272 \mu \mathrm{g} / \mathrm{L}$ for $\mathrm{Cu}, 520 \pm 240 \mu \mathrm{g} / \mathrm{L}$ for $\mathrm{Zn}, 113 \pm$ $105 \mu \mathrm{g} / \mathrm{L}$ for Cd, $550 \pm 237 \mu \mathrm{g} / \mathrm{L}$ for $\mathrm{Pb}, 312 \pm 97 \mu \mathrm{g} / \mathrm{L}$ for Ni and $77 \pm 56 \mu \mathrm{g} / \mathrm{L}$ for Co (Table 2). All these concentrations are much lower than the limit

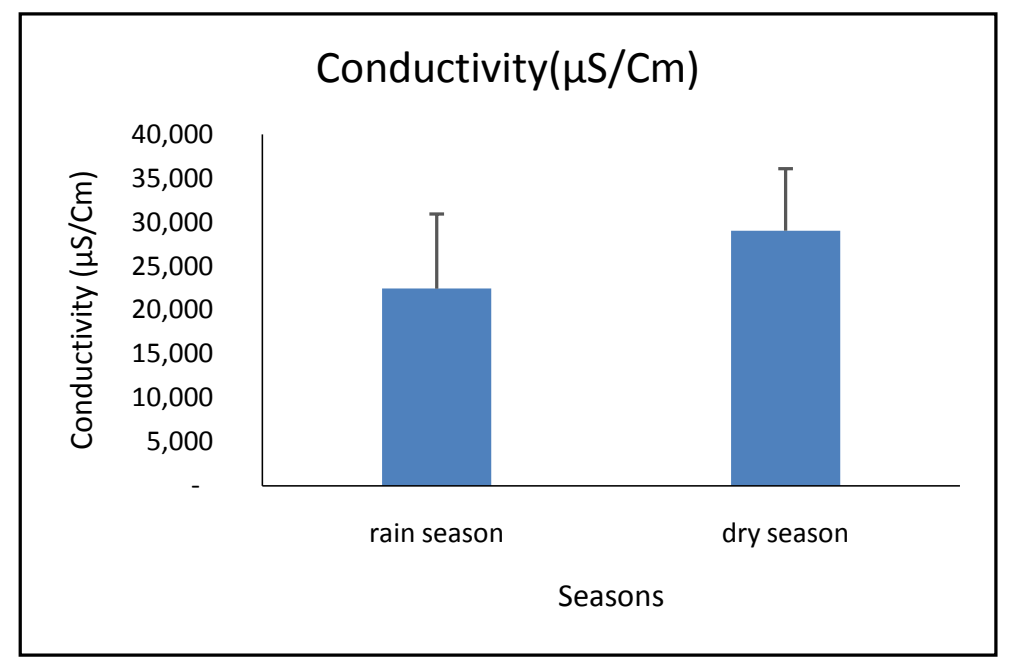

Figure 4. Seasonal variations of conductivity in the leachate.

Table 2. Metallic trace elements concentrations in the leachate.

\begin{tabular}{cccc}
\hline Parameters & L1 & L2 & variation $(\mathrm{mg} / \mathrm{L})$ \\
\hline $\mathrm{Fe}(\mu \mathrm{g} / \mathrm{L})$ & 4570 & 8330 & $3-5500$ \\
& $70-10,540$ & $70-34,100$ & \\
$\mathrm{Cu}(\mu \mathrm{g} / \mathrm{L})$ & 400 & 400 & $0.005-10$ \\
& $210-1120$ & $80-800$ & $0.03-1000$ \\
$\mathrm{Zn}(\mu \mathrm{g} / \mathrm{L})$ & 510 & 520 & \\
& $197-840$ & $204-1020$ & $1-5$ \\
$\mathrm{Cd}(\mu \mathrm{g} / \mathrm{L})$ & 90 & 130 & \\
& $50-250$ & $30-360$ & $0.015-13$ \\
$\mathrm{~Pb}(\mu \mathrm{g} / \mathrm{L})$ & 540 & 560 & \\
& $\mathrm{Nd}-820$ & $\mathrm{Nd}-950$ & $0.015-14$ \\
$\mathrm{Ni}(\mu \mathrm{g} / \mathrm{L})$ & 310 & 320 & \\
$\mathrm{Co}(\mu \mathrm{g} / \mathrm{L})$ & $210-430$ & $250-410$ & \\
& 90 & $70-130$ & \\
\hline
\end{tabular}


concentrations set by WHO [42] except for Cd, which has a concentration close to the limit value.

Of all these trace metals, $\mathrm{Fe}$ exhibited the highest concentrations in the two study stations; this could, be explained by the predominance of $\mathrm{Fe}$ among the metal scrap of the landfill. The dark brown color of the leachate was mainly attribute to the oxidation of ferrous to ferric form and the formation of ferric hydroxide colloids and complexes with fulvic/humic substance [43]. According to Legret [44], nickel and zinc are the most leachable elements in fresh waste. They may both come from special wastes such as batteries, paint pigments, stabilizers or rubbers [45] [46]. The presence of $\mathrm{Pb}$ in the leachate indicates the discharge of batteries, Pb-based paint, chemicals from photographic treatments. Copper, for its part, could originate from several types of waste, such as printing inks or paints, cardboard, rubber and textiles [47].

The concentrations of the trace metals of the Akouedo landfill leachate are globally identical to those of the leachates generated by other garbage dumps and are of the same order of magnitude as the results obtained by other landfills (Table 3). The concentrations of trace metals in the leachate from the Akouédo landfill are low and do not reflect the actual metal concentrations of the of old landfills. The majority of trace metals, mainly copper, nickel, lead, iron, zinc and cadmium could be trapped within the Akouedo landfill [48] [49]; that is the reason trace elements concentrations are low. Baccini et al. [48] estimate that more than $99.9 \%$ of heavy metals remain trapped in the landfill after 30 years. For François [50], 95\% of the metals remained trapped within the mass of waste at the end of 4 years.

It should be noted that the concentrations of the various metals obtained are in the range of those from the so-called old leachate [16] [41] [42] [27] [54] (Table 3). Studies have shown that the older the waste, the more stable the metals within the waste [50]. François [50] has also shown through fractionation protocols applied to wastes of different ages that metals are more easily remobilizable in a young waste than in an old waste. The concentrations of trace elements obtained in the leachate from the Akouédo landfill might be due to the composition of the waste, the basic character and the age of the landfill. The metal charge, however, poses an enormous risk to groundwater because there is direct contact of the leachate with the underlying aquifer in the landfill area and also for the surrounding surface waters.

The seasonal variations of trace metals in the leachate are shown in Table 4. High concentrations of $\mathrm{Ni}, \mathrm{Fe}$ and $\mathrm{Zn}$ metals are observed during the rainy season; $\mathrm{Pb}, \mathrm{Cu}, \mathrm{Co}$ and $\mathrm{Cd}$ have high concentrations during the dry season. The ANOVA statistical analysis $(\mathrm{p}<0.05)$ indicates that there is a significant difference between the rainy season and the dry season for trace metals such as $\mathrm{Pb}$, $\mathrm{Cd}, \mathrm{Zn}$ and $\mathrm{Cu}$. This result can be explained by a dilution of the leachate by precipitation water. On the other hand, no significant difference was observed between the two seasons for $\mathrm{Fe}$, $\mathrm{Co}$ and $\mathrm{Ni}$. High concentrations of $\mathrm{Zn}$ during the 
Table 3. Comparison of trace metals concentrations of leachate from the Akouedo landfill with leachate from other landfills.

\begin{tabular}{|c|c|c|c|c|c|c|c|c|}
\hline Stations & $\mathrm{Fe}(\mu \mathrm{g} / \mathrm{L})$ & $\mathrm{Zn}(\mu \mathrm{g} / \mathrm{L})$ & $\mathrm{Pb}(\mu \mathrm{g} / \mathrm{L})$ & $\mathrm{Cd}(\mu \mathrm{g} / \mathrm{L})$ & $\mathrm{Cu}(\mu \mathrm{g} / \mathrm{L})$ & $\mathrm{Ni}(\mu \mathrm{g} / \mathrm{L})$ & Co $(\mu g / L)$ & References \\
\hline Akouedo landfill & $72-34100$ & $197-1015$ & $233-947$ & $29-362$ & $83-1117$ & $95-412$ & $8-176$ & Present study \\
\hline $\begin{array}{c}\text { Mashhad } \\
\text { landfill (Iran) }\end{array}$ & & & $200-450$ & 7 & $30-400$ & $200-450$ & & [27] \\
\hline $\begin{array}{l}\text { Effurun landfill. } \\
\text { (Nigeria) }\end{array}$ & 17490 & 197 & 88 & & 4030 & & & [51] \\
\hline $\begin{array}{l}\text { Oblogo landfill } \\
\text { (Ghana) }\end{array}$ & $3830-5960$ & $7420-$ & & $140-200$ & $8970-13780$ & & & [16] \\
\hline $\begin{array}{c}\text { Ibb City landfill. } \\
\text { Yemen }\end{array}$ & $46000-47700$ & $56000-85500$ & $2600-2850$ & $250-300$ & 21500 & $1700-1800$ & & [52] \\
\hline Henchir & & & & & & & & \\
\hline $\begin{array}{c}\text { ElYahoudia } \\
\text { landfill }\end{array}$ & $26-76$ & $30-800$ & $10-180$ & $10-30$ & $40-90$ & $130-670$ & & [53] \\
\hline $\begin{array}{c}\text { Etueffont } \\
\text { landfill (France) }\end{array}$ & 2630 & $300-1850$ & 100 & 10 & $0-1770$ & $170-8640$ & 60 & [54] \\
\hline $\begin{array}{l}\text { El Jadida landfill } \\
\text { (Maroc) }\end{array}$ & 24000 & $0-747.2$ & & $0-34$ & $0-159$ & $0-133.8$ & & [41] \\
\hline WHO & $3-5500$ & $0.03-1000$ & $1-5$ & $0.0001-0.4$ & $0.005-10$ & $0.015-13$ & $0.015-14$ & [42] \\
\hline
\end{tabular}

Table 4. Seasonal variations in metal concentrations in leachate.

\begin{tabular}{|c|c|c|c|c|c|c|c|}
\hline Seasons & $\mathrm{Fe}(\mu \mathrm{g} / \mathrm{L})$ & $\mathrm{Cu}(\mu \mathrm{g} / \mathrm{L})$ & $\mathrm{Zn}(\mu \mathrm{g} / \mathrm{L})$ & $\mathrm{Cd}(\mu \mathrm{g} / \mathrm{L})$ & $\mathrm{Pb}(\mu \mathrm{g} / \mathrm{L})$ & $\mathrm{Ni}(\mu \mathrm{g} / \mathrm{L})$ & Co $(\mu \mathrm{g} / \mathrm{L})$ \\
\hline Rain Seasons & $8.92 \pm 9.70$ & $0.28 \pm 0.12$ & $0.63 \pm 0.21$ & $0.05 \pm 0.02$ & $0.42 \pm 0.15$ & $0.32 \pm 0.11$ & $10.09 \pm 0.04$ \\
\hline Dry Seasons & $0.09 \pm 0.03$ & $0.70 \pm 0.33$ & $0.27 \pm 0.10$ & $0.25 \pm 0.10$ & $0.82 \pm 0.10$ & $0.28 \pm 0.08$ & $80.11 \pm 0.05$ \\
\hline
\end{tabular}

rainy season show that other factors such as chemical and physical biological processes within the landfill can influence the seasonal variation of metals in the leachate. Further studies are needed to better explain the seasonal variation of $\mathrm{Zn}$ in leachate from the Akouedo landfill.

\subsection{Evaluation of the Impact of Leachate on the Quality of Groundwater near the Akouedo Landfill}

\subsubsection{Physico-Chemical Characterization of Groundwater \\ 1) $\mathrm{pH}$ and Temperature}

The physical and chemical parameters of the groundwater are displayed in Table 5. The M'badon groundwater $\mathrm{pH}$ is between 4.72 and 6.46 , showing its acidic character compared to the leachate which is more basic. The average M'badon groundwater temperature is between $24.49^{\circ} \mathrm{C}$ and $30.23^{\circ} \mathrm{C}$ (Table 5). The M'badon groundwater temperature is well above $25^{\circ} \mathrm{C}$, a tolerated value for water intended for human consumption in France (French Standards, 1999) and in Morocco (Moroccan Standards, 2002). In accordance with international standards (Table 6), the M'badon groundwater is not suitable for domestic use especially for drinking water.

The M'badon groundwater $\mathrm{pH}$ and temperature seasonal variation are shown in Figure 5. The temperature and $\mathrm{pH}$ are relatively lower during the rainy season than during the dry season, due to dilution and ambient temperature, respectively. 
Table 5. Physical parameters of groundwater.

\begin{tabular}{ccccc}
\hline Parameters & $\mathrm{pH}$ & Temperature $\left({ }^{\circ} \mathrm{C}\right)$ & $\begin{array}{c}\text { Conductivity } \\
(\mu \mathrm{s} / \mathrm{Cm})\end{array}$ & Salinity (\%) \\
\hline P1 & 5.36 & 27.05 & 72.29 & 0.03 \\
& $4.78-6.46$ & $24.02-30.23$ & $43-86$ & $0.02-007$ \\
P2 & 5.31 & 26.97 & 51.71 & 0.02 \\
& $4.72-6.42$ & $24.49-28.97$ & $5-39$ & $0-0.1$ \\
\hline
\end{tabular}

Table 6. Recommended standard for WHO, US EPA and EU for drinking water.

\begin{tabular}{|c|c|c|c|c|c|c|c|}
\hline \multirow{2}{*}{ Parameters } & \multicolumn{2}{|c|}{$\begin{array}{c}\text { BIS standards } \\
\text { (IS 10500: 1991) [55] }\end{array}$} & \multirow{2}{*}{$\begin{array}{c}\text { WHO } \\
(2002) \\
{[56]}\end{array}$} & \multirow{2}{*}{$\begin{array}{c}\text { WHO } \\
(2008) \\
{[56]}\end{array}$} & \multirow{2}{*}{$\begin{array}{c}\text { WHO } \\
(2011) \\
{[57]}\end{array}$} & \multirow{2}{*}{$\begin{array}{c}\text { US EPA } \\
(2009) \\
{[58]}\end{array}$} & \multirow{2}{*}{$\begin{array}{l}\text { UE } \\
{[59]}\end{array}$} \\
\hline & $\begin{array}{c}\text { Limite } \\
\text { desirable }\end{array}$ & $\begin{array}{c}\text { Limite } \\
\text { permitted }\end{array}$ & & & & & \\
\hline $\mathrm{pH}$ & $6.5-8.5$ & $6.5-8.5$ & $6.5-9.2$ & & & & \\
\hline $\mathrm{Fe}(\mathrm{mg} / \mathrm{L})$ & 0.3 & 1 & 0.3 & 0.3 & 0.3 & 0.3 & - \\
\hline $\mathrm{Cd}(\mathrm{mg} / \mathrm{L})$ & 0.01 & - & 0.005 & 0.003 & 0.003 & 0.005 & 0.003 \\
\hline $\mathrm{Cu}(\mathrm{mg} / \mathrm{L})$ & 0.05 & 1.5 & 1 & 2 & 2 & 1.3 & 2 \\
\hline $\mathrm{Zn}(\mathrm{mg} / \mathrm{L})$ & 5 & 15 & 5 & 3 & 3 & 5 & 3 \\
\hline $\mathrm{Pb}(\mathrm{mg} / \mathrm{L})$ & 0.05 & - & 0.05 & 0.01 & 0.01 & 0.015 & 0.01 \\
\hline $\mathrm{Ni}(\mathrm{mg} / \mathrm{L})$ & - & - & & $0.15-13$ & 0.07 & - & 0.02 \\
\hline Co (mg/L) & - & - & & 0.04 & - & - & - \\
\hline
\end{tabular}
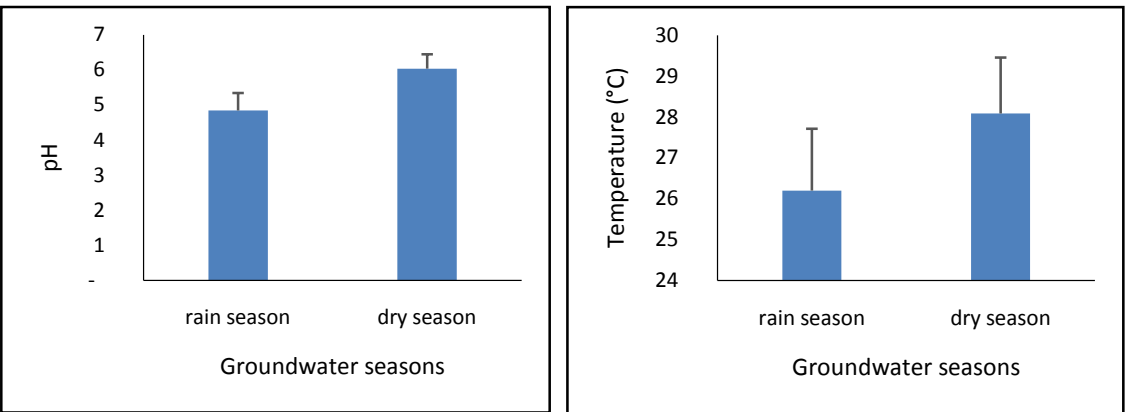

Figure 5. Seasonal variation of $\mathrm{pH}$ and Temperature in groundwater.

\section{2) Conductivity}

Table 5 presents the M'badon groundwater conductivity. The conductivity is generally below $86 \mu \mathrm{S} / \mathrm{cm}$, showing a low mineralization of the groundwater. The M'badon conductivity is lower than that found in groundwater located near a landfill in France (32 - $245 \mu \mathrm{S} / \mathrm{cm}$ ) [54] and in Morocco in the El Jadida public dump (Morocco) $(1510-8400 \mu \mathrm{S} / \mathrm{cm})[41]$.

\subsubsection{Total Concentration of Groundwater in Traces of Metal}

The M'Badon groundwater trace metals concentrations are shown in Table 7. Trace metal concentrations are lower than those of the Akouédo landfill leachate but above the WHO standards, except for $\mathrm{Zn}$, which has a lower concentration $(30 \mu \mathrm{g} / \mathrm{L})$ than the standard $(3000 \mu \mathrm{g} / \mathrm{L}) . \mathrm{Cu}$ is the most recovered element in 
Table 7. Concentrations of trace metal in groundwater.

\begin{tabular}{ccc}
\hline Parameters & P1 & P2 \\
\hline $\mathrm{Fe}(\mu \mathrm{g} / \mathrm{L})$ & 321 & $\mathrm{Nd}$ \\
& $87-598$ & 194.2 \\
$\mathrm{Cu}(\mu \mathrm{g} / \mathrm{L})$ & 1041 & $7-864$ \\
& $16-3932$ & 28.83 \\
$\mathrm{Zn}(\mu \mathrm{g} / \mathrm{L})$ & 30.83 & $17-39$ \\
& $3-56$ & 31 \\
$\mathrm{Cd}(\mu \mathrm{g} / \mathrm{L})$ & 60 & $4-132$ \\
$\mathrm{~Pb}(\mu \mathrm{g} / \mathrm{L})$ & $7-158$ & 502 \\
& 764 & $\mathrm{nd}-502$ \\
$\mathrm{Ni}(\mu \mathrm{g} / \mathrm{L})$ & $\mathrm{nd}-764$ & 64 \\
& 51.33 & $\mathrm{nd}-64$ \\
$\mathrm{Co}(\mu \mathrm{g} / \mathrm{L})$ & $3-103$ & 44 \\
& 48.5 & $\mathrm{nd}-44$ \\
\hline
\end{tabular}

high amount $(3932 \mu \mathrm{g} / \mathrm{L})$ followed by $\mathrm{Pb}(764 \mu \mathrm{g} / \mathrm{L})$. The results obtained from this study are similar to those obtained by Kanmani et al. [15]. The ANOVA analysis $(\mathrm{p}<0.05)$ shows that there is no significant difference between the stations $\mathrm{P} 1$ and P2. Of all these observations, it is difficult to conclude that the Mbadon groundwater is affected by the metal contamination of the Akouedo landfill leachate. According to several authors [1] [16] [51] [57] [60] (Table 8)., the migration of metals into a permeable medium is complex from the reaction point of view (physicochemical reactions involved). Similarly, the presence of clay lenses and shales can constitute a retention factor for these trace elements, which contribute to their entrapment in the surface layer. Some metallic pollutants illustrate a "hunting phenomenon" of the input signal either instantaneously or with a certain lag. The latter is variable because it depends on the rains intensity, the nature of the chemical element, the distance from the water source of the discharge and the position of the trace metal with respect to the direction of the flow [47].

\subsection{Evaluation of the Impact of Leachate on the Quality of Lagoon Water (M'Badon Bay) near the Akouédo Landfill}

\subsubsection{Physico-Chemical Characterization of Lagoon Water}

\section{1) $\mathrm{pH}$}

The $\mathrm{pH}$ of the M'badon bay varies from 5.94 to 7.58 (Table 9). Mean $\mathrm{pH}$ varied significantly (ANOVA, $\mathrm{P}<0.05$ ) according to the hydroclimatic season. Mean $\mathrm{pH}$ is 7.79 during the dry season while those of the rainy and flood season are respectively 6.86 and 6.64 (Table 10). Data collected in other sectors of the lagoon show the same trend. The $\mathrm{pH}$ is higher during the period of oceanic influence (dry season) and lower during the period of continental influence [62] [63]. Therefore, the $\mathrm{pH}$ variations observed in the M'badon bay of the Ebrie lagoon do not appear to be due to the influence of the Akouedo landfill on the coastal ecosystem.

\section{2) Temperature}


Table 8. Comparison of the concentration of metals of groundwater in the vicinity of the Akouédo landfill to those reported in groundwater in some areas and to WHO quality standards.

\begin{tabular}{|c|c|c|c|c|c|c|c|}
\hline & Akouedo landfill & Alimosho landfill & Oujda landfill & Oblogo landfill & $\begin{array}{l}\text { Effurn Delta } \\
\text { State landfill }\end{array}$ & $\begin{array}{c}\text { Kapuluppada MSW } \\
\text { landfill }\end{array}$ & $\begin{array}{c}\text { Guidelines } \\
\mathrm{WHO}^{*}(\mathrm{mg} / \mathrm{L})\end{array}$ \\
\hline & (Cote d'Ivoire) & Lagos (Nigeria) & (Maroc) & (Ghana) & (Nigeria) & (Visakhapatnam Inde) & \\
\hline $\mathrm{Fe}(\mathrm{mg} / \mathrm{L})$ & $0.087-0.598$ & 2.45 & $0-0.91$ & $1.67-5.1$ & 1.45 & 4.55 & 0.3 \\
\hline $\mathrm{Cu}(\mathrm{mg} / \mathrm{L})$ & $0.007-3.932$ & 2.26 & nd & $1.47-3.36$ & 0.25 & $88 \pm 36$ & 2 \\
\hline $\mathrm{Zn}(\mathrm{mg} / \mathrm{L})$ & $0.003-0.056$ & 23.71 & $0-042$ & $2.1-3.91$ & 1.2 & $0.25-5.711$ & 3 \\
\hline $\mathrm{Pb}(\mathrm{mg} / \mathrm{L})$ & $0.502-0.764$ & 0.06 & nd & nd & $<0.001$ & $0.045-4.287$ & 0.01 \\
\hline $\mathrm{Cd}(\mathrm{mg} / \mathrm{L})$ & $0.004-0.158$ & 0.03 & $0.01-0.32$ & $0.04-0.14$ & nd & $0.002-2.482$ & 0.003 \\
\hline Co (mg/L) & $0.044-0.053$ & nd & nd & nd & nd & $0.001-0.007$ & 0.04 \\
\hline $\mathrm{Ni}(\mathrm{mg} / \mathrm{L})$ & $0.003-0.103$ & $15.1-43.9$ & $0-0.14$ & nd & nd & 0.8 & 0.07 \\
\hline References & Present study & [1] & [61] & [16] & [51] & [61] & [57] \\
\hline
\end{tabular}

${ }^{*}$ Water consumption. nd: non detected.

The temperature varied from $23.43^{\circ} \mathrm{C}$ to $31.27^{\circ} \mathrm{C}$ in the M'Badon bay (Table 9). Maximum temperatures are observed during the dry season and minimum temperatures during the rainy and flood season of the Comoe River (Table 10). Those results were identical to those observed by Kouassi [63]. According to this author, the high temperature in the dry season was due to the insolation and the low temperature to the upwelling of cold water during the month of August. Moreover, the spatial variability across the lagoon is relatively low in the order of $1^{\circ} \mathrm{C}$. This spatial variability of waters was due to the backgrounds areas, to the inputs of continental and oceanic waters at different period [64]. The temperature of ocean water are constantly colder than the lagoon waters, this showed a few positif horizontal gradient from Vridi channel to upstream. Variations of temperature and $\mathrm{pH}$ did provide of the influence of Akouedo landfill to the lagoon ecosystem.

The average temperature of the M'badon bay is $28.09^{\circ} \mathrm{C} \pm 2.04^{\circ} \mathrm{C}$ (Table 9). Maximum temperatures are observed during the dry season and the minimum temperatures during the rainy and flood season of the Comoe River (Table 10). The temperatures are identical to those observed by Kouassi [63]. According to this author, the high temperatures in the dry season are due to insolation and low temperatures during the upwelling period, occurring in August of the year. Moreover, the spatial variability over the whole lagoon is relatively low in the order of $1^{\circ} \mathrm{C}$. This spatial variability of the lagoon is due to the inputs of continental and oceanic waters at different period [64] [65]. The temperature of the oceanic waters being constantly colder than that of the lagoon waters, there is a small positive horizontal gradient of the Vridi channel upstream. Temperature variations do not therefore appear to be due to the influence of the Akouedo landfill on the lagoon ecosystem. 
Table 9. Physical parameters of lagoon waters.

\begin{tabular}{ccccc}
\hline STATIONS & $\mathrm{pH}$ & $\mathrm{T}\left({ }^{\circ} \mathrm{C}\right)$ & $\begin{array}{c}\text { Conductivity } \\
(\mu \mathrm{s} / \mathrm{Cm})\end{array}$ & Salinity $(\% \mathrm{o})$ \\
\hline S1 & 6.97 & 28.02 & 6841 & 3.74 \\
S2 & 6.88 & 27.65 & 7393.71 & 4.05 \\
S3 & 6.77 & 27.68 & 7154.86 & 4.12 \\
S4 & 6.94 & 28.00 & 7045.43 & 3.89 \\
S5 & 6.85 & 28.00 & 6946.71 & 4.35 \\
S6 & 6.88 & 27.97 & 7645.14 & 4.21 \\
S7 & 6.92 & 29.27 & 7545.40 & 4.40 \\
S8 & 6.93 & 28.63 & 6894.00 & 4.01 \\
M'Badon & $6.90 \pm 0.36$ & $28.09 \pm 2.04$ & $7181 \pm 8675$ & \\
\hline
\end{tabular}

Table 10. Seasonal variation of physical parameters in lagoon waters.

\begin{tabular}{cccc}
\hline PARAMETERS & \multicolumn{3}{c}{ SEASONS } \\
\hline $\mathrm{pH}$ & Rain & Floods & Dry \\
Temperature $\left({ }^{\circ} \mathrm{C}\right)$ & 6.86 & 6.64 & 7.29 \\
Conductivity $(\mu \mathrm{S} / \mathrm{Cm})$ & 25.65 & 28.48 & 29.38 \\
\hline
\end{tabular}

\section{3) Conductivity}

Mean conductivity of the M'badon bay is $7181 \pm 8675 \mu \mathrm{S} / \mathrm{cm}$ (Table 9). Seasonal variations of the surface water conductivity are very marked, rising from $782 \mu \mathrm{S} / \mathrm{cm}$ during the flood and rainfall seasons $(6161 \mu \mathrm{S} / \mathrm{cm})$ to more than $17,544 \mu \mathrm{S} / \mathrm{cm}$ during the dry period (Table 10). According to Dufour [64], as the circulation is of the estuarine type in the eastern part of the Ebrié lagoon, seawater flows in depth towards the upstream forming a wedge of salt water which undergoes twice-daily pulsations The amplitude of the tides and the regime of rivers. Its extension is maximum in the high dry season at high tide [65]. On the surface, there is an inverse current of less salty water becoming intense during periods of rains and flood of the Comoe and limiting then the extension of the salt water to a few meters of thickness [63]. All the above shows that the conductivities observed in the Bay of M'Badon and in the lagoon of Anna are related to the hydrology of the lagoon.

\subsubsection{Concentration of Metals in Lagoon Waters (M'Badon Bay)}

Mean concentrations and seasonal variations of trace metals in the Mbadon bay waters of the Ebrié lagoon are presented in Table 11 and Table 12.

Iron

Mean Fe concentrations are between 220 and $1120 \mu \mathrm{g} / \mathrm{L}$. The statistical analysis (ANOVA) shows that there is no significant difference between the stations. However, a significant difference $(\mathrm{p}<0.05)$ was observed between seasons in 
Table 11. Concentrations of metal trace elements in lagoon waters (M'Badon).

\begin{tabular}{cccccccc}
\hline Station & $\mathrm{Fe}(\mathrm{mg} / \mathrm{L})$ & $\mathrm{Cu}(\mathrm{mg} / \mathrm{L})$ & $\mathrm{Zn}(\mathrm{mg} / \mathrm{L})$ & $\mathrm{Cd}(\mathrm{mg} / \mathrm{L})$ & $\mathrm{Pb}(\mathrm{mg} / \mathrm{L})$ & $\mathrm{Ni}(\mathrm{mg} / \mathrm{L})$ & $\mathrm{Co}(\mathrm{mg} / \mathrm{L})$ \\
\hline $\mathrm{S} 1$ & 0.59 & 0.37 & 0.04 & 0.07 & 0.63 & 0.03 & 0.04 \\
$\mathrm{~S} 2$ & 1.10 & 0.15 & 0.04 & 0.08 & 0.75 & 0.07 & 0.14 \\
$\mathrm{~S} 3$ & 1.12 & 0.16 & 0.05 & 0.09 & 0.83 & 0.07 & 0.09 \\
$\mathrm{~S} 4$ & 0.60 & 0.45 & 0.06 & 0.10 & 0.65 & 0.08 & 0.10 \\
$\mathrm{~S} 5$ & 0.76 & 0.14 & 0.03 & 0.09 & 0.26 & 0.08 & 0.09 \\
$\mathrm{~S} 6$ & 0.56 & 0.23 & 0.04 & 0.10 & 0.26 & 0.11 & 0.11 \\
$\mathrm{~S} 7$ & 1.03 & 0.10 & 0.03 & 0.10 & 0.86 & 0.12 & 0.10 \\
$\mathrm{~S} 8$ & 0.91 & 0.06 & 0.04 & 0.09 & 0.43 & 0.14 & 0.09 \\
\hline
\end{tabular}

Table 12. Seasonal variations in heavy metal content in lagoon waters.

\begin{tabular}{cccc}
\hline & & M’Badon & \\
\cline { 2 - 4 } PARAMETERS & Rain & Floods & Dry \\
\hline $\mathrm{Fe}(\mathrm{mg} / \mathrm{L})$ & 0.23 & 1.49 & 0.25 \\
$\mathrm{Cu}(\mathrm{mg} / \mathrm{L})$ & 0.04 & 0.03 & 0.50 \\
$\mathrm{Zn}(\mathrm{mg} / \mathrm{L})$ & 0.04 & 0.04 & 0.04 \\
$\mathrm{Cd}(\mathrm{mg} / \mathrm{L})$ & 0.02 & 0.01 & 0.24 \\
$\mathrm{~Pb}(\mathrm{mg} / \mathrm{L})$ & 0.08 & 0.30 & 0.70 \\
$\mathrm{Ni}(\mathrm{mg} / \mathrm{L})$ & 0.03 & 0.04 & 0.13 \\
$\mathrm{Co}(\mathrm{mg} / \mathrm{L})$ & - & - & 0.09 \\
\hline
\end{tabular}

MBadon Bay. The highest Fe concentrations are observed during the flood season $(1490 \mu \mathrm{g} / \mathrm{L})$ and the lowest during the wet season $(230 \mu \mathrm{g} / \mathrm{L})$.

\section{Copper}

Mean $\mathrm{Cu}$ concentrations in the MBadon Bay range from $60 \mu \mathrm{g} / \mathrm{L}$ to $1440 \mu \mathrm{g} / \mathrm{L}$. They significantly $(\mathrm{p}<0.05)$ vary between seasons. The highest concentrations are obtained during the dry season $(500 \mu \mathrm{g} / \mathrm{L})$. No significant difference was observed between stations.

\section{Zinc}

The average $\mathrm{Zn}$ concentrations obtained in each station are in the range of 30 $\mu \mathrm{g} / \mathrm{L}$ to $50 \mu \mathrm{g} / \mathrm{L}$. This metal does not exhibit significant inter-station variations $(\mathrm{p}<0.05)$. Maximum concentrations were obtained during the dry season in the M'Badon Bay waters with a significant difference $(\mathrm{p}<0.05)$ between seasons.

\section{Cadmium}

Cadmium concentrations are high in the dry season and low in the rainy season. Statistical analysis (ANOVA) showed a significant difference $(\mathrm{p}<0.05)$ between seasons and no difference between stations.

\section{Lead}

Mean lead concentrations range from $260 \mu \mathrm{g} / \mathrm{L}$ (S6) to $860 \mu \mathrm{g} / \mathrm{L}$ (S7) in the 
Mbadon bay lagoon waters. There is no statistical difference $(\mathrm{p}<0.05)$ between the stations in the in the bay. The seasonal variation in M'Badon Bay showed that the maximum level $(700 \mu \mathrm{g} / \mathrm{L})$ was obtained during the dry season with a significant difference $(\mathrm{p}<0.05)$ between the seasons.

\section{Nickel}

Mean nickel concentrations are between 30 and $140 \mu \mathrm{g} / \mathrm{L}$ (Table 11). There is no significant difference between the stations in the M'Badon bay. However, the ANOVA analysis $(\mathrm{p}<0.05)$ shows a significant difference between the seasons at M'Badon Bay. Maximum concentrations were recorded during the dry season.

\section{Cobalt}

Co concentrations were only obtained during the dry season. There are no significant differences $(\mathrm{p}<0.05)$ between inter-seasons and inter-stations in the M'Badon bay. The variation of the concentrations between the stations is of the order of $40 \mu \mathrm{g} / \mathrm{L}$ to $110 \mu \mathrm{g} / \mathrm{L}$. The high concentrations observed during the dry season are probably due to lack of algae, water evaporation and lack of dilution.

Except Zinc, trace element concentrations in the M'Badon Bay are above WHO water consumption standards (Table 13 and Table 14). This may be due to the proximity of the landfill and to anthropogenic activities in the M'Badon area (agriculture, fishing, urbanization, etc.).

The M'Badon bay waters are more contaminated in lead and cadmium than other sectors of the Ebrié lagoon [57] [66] [70]. This may be attributed to the nature of the wastes (industrial waste, electronic and household) of the Akouédo landfill. However, trace metals concentrations of the M'Badaon bay surface water are lower than those of the Akouedo landfill leachate. These low concentrations are probably due to the process of sedimentation, adsorption, dilution and flocculation of metals during their transport.

\section{Conclusion}

The results obtained from this study show that the Akouedo landfill leachate has no impact on the groundwater and the Mbadon bay surface waters. The leachate

Table 13. Comparison of metal concentrations in the waters of M'Badon Bay with those of certain bays in the Ebrié lagoon.

\begin{tabular}{cccccc}
\hline Parameters & Cocody [66] & Bingerville [66] & $\begin{array}{c}\text { Biétri (SIR) } \\
{[66]}\end{array}$ & $\begin{array}{c}\text { Marcory } \\
\text { (Biafra) [66] }\end{array}$ & This study \\
\hline Temperature & 28.46 & 29.15 & 29.73 & 28.74 & 28.13 \\
$\mathrm{pH}$ & 7.51 & 7.28 & 8.10 & 7.34 & 6.89 \\
$\begin{array}{c}\text { Conductivity } \\
(\mathrm{Ms} / \mathrm{Cm})\end{array}$ & 18.16 & 21.76 & 25.44 & 19.42 & 7.18 \\
$\mathrm{Salinity}$ & 1.03 & 1.13 & 1.44 & 1.18 & 4.1 \\
$\mathrm{~Pb}(\mu \mathrm{g} / \mathrm{L})$ & 590 & 75.2 & 625 & 535 & 514.18 \\
$\mathrm{Cd}(\mu \mathrm{g} / \mathrm{L})$ & 12.5 & 3 & 32.5 & 40 & 90 \\
$\mathrm{Ni}(\mu \mathrm{g} / \mathrm{L})$ & 157.5 & 21.5 & 230 & 135 & 83 \\
$\mathrm{Zn}(\mu \mathrm{g} / \mathrm{L})$ & 14662.5 & 1415 & 23187.5 & 39315 & 40 \\
\hline
\end{tabular}


Table 14. Comparison of concentrations of trace metallic elements of surface waters near landfills in other regions to those of M'Badon Bay.

\begin{tabular}{|c|c|c|c|c|c|c|c|}
\hline & $\begin{array}{l}\text { M'Badon } \\
\text { bay (Cote }\end{array}$ & $\begin{array}{l}\text { Sakumo } \\
\text { lagoon. } \\
\text { (Ghana) }\end{array}$ & $\begin{array}{l}\text { Ikpoba in } \\
\text { Benin City }\end{array}$ & $\begin{array}{c}\text { Lac } \\
\text { (Kenya) }\end{array}$ & $\begin{array}{c}\text { Ebrié } \\
\text { lagoon }\end{array}$ & Cocody bay & $\begin{array}{c}\text { guidelines } \\
\text { WHO }\end{array}$ \\
\hline & d'Ivoire) & & (Nigeria) & & $\begin{array}{c}\text { (Côte } \\
\text { d'Ivoire) }\end{array}$ & $\begin{array}{c}\text { (Cote } \\
\text { d'Ivoire) }\end{array}$ & \\
\hline $\mathrm{Zn}(\mu \mathrm{g} / \mathrm{L})$ & $6-166$ & $77-160$ & 24 & $40-235$ & - & $36-376$ & 3000 \\
\hline $\mathrm{Pb}(\mu \mathrm{g} / \mathrm{L})$ & $12-1371$ & 57 & 70 & $25-563$ & $75.2-670$ & Nd - 96 & 10 \\
\hline $\mathrm{Cd}(\mu \mathrm{g} / \mathrm{L})$ & $1-322$ & 49 & - & $2-43$ & $3-47.5$ & $30-47$ & 3 \\
\hline $\mathrm{Ni}(\mu \mathrm{g} / \mathrm{L})$ & $3-257$ & & 141 & nd -288 & $21.5-262.5$ & 6 & 70 \\
\hline $\mathrm{Cu}(\mu \mathrm{g} / \mathrm{L})$ & $60-450$ & $112-158$ & & & & $79-91$ & \\
\hline References & $\begin{array}{l}\text { Present } \\
\text { study }\end{array}$ & [67] & [68] & [69] & [66] & [70] & [57] \\
\hline
\end{tabular}

is characterized by a basic $\mathrm{pH}$, and a conductivity fluctuating between 10,060 and $37,990 \mu \mathrm{S} \cdot \mathrm{cm}^{-1}$. The groundwater in the vicinity of the Akouedo landfill shows an acidic character and a conductivity generally below $86 \mu \mathrm{S} / \mathrm{cm}$. The $\mathrm{pH}$ of the M'badon bay varies from 5.94 to 7.58 and the mean conductivity between $7181 \pm 8675 \mu \mathrm{S} / \mathrm{cm}$. The high conductivity of the Mbadon bay waters is attributed to the oceanic influence of the bay. The presence of trace metals observed in the leachate can be attributed to the composition of the landfill waste which is typical for a dominant household character. Trace metal concentrations of the groundwater and the Mbadon surface waters are lower than those of the Akouédo landfill leachate. The concentrations of the groundwater and the M'Badon bay waters trace elements were generally higher than the permissible levels specified by WHO.

\section{References}

[1] Akoteyon, I.S., Mbata, U.A. and Olalude, G.A. (2011) Investigation of Heavy Metal Contamination in Groundwater around Landfill Site in a Typical Sub-Urban Settlement in Alimosho, Lagos-Nigeria. Journal of Applied in Environmental Sciences Sanitation, 6, 155-163.

[2] Stewart, M.O. and Ramón, J. (2012) Sustainable Sanitary Landfills for Neglected Small Cities in Developing Countries: The Semi-Mechanized Trench Method from Villanueva, Honduras. Waste Management, 32, 2535-2551. https://doi.org/10.1016/j.wasman.2012.07.030

[3] Øygard, J.K., Maage, A. and Gjengedal, E. (2011) The Effects of Reduction of the Deposited Waste on Short-Term Landfill Leachate Composition of a Landfill: A Case Study in Norway. Water and Environment Journal, 25, 208-213. https://doi.org/10.1111/j.1747-6593.2009.00212.x

[4] Bozkurt, S., Moreno, L. and Neretnieks, I. (2000) Long-Term Processes in Waste Deposits. Science of the Total Environment, 250, 101-121. https://doi.org/10.1016/S0048-9697(00)00370-3

[5] Kulikowska, D. and Klimiuk, E. (2008) The Effect of Landfill Age on Municipal Leachate Composition. Bioresource Technology, 99, 5981-5985.

https://doi.org/10.1016/j.biortech.2007.10.015 
[6] Christensen, T.H., Kjeldsen, P., Bjerg, P.L., Jensen, D.L., Christensen, J.B., Baun, A., Albrechtsen, H.J. and Heron, G. (2001) Biogeochemistry of Landfill Leachate Plumes. Applied Geochemistry, 16, 659-718. https://doi.org/10.1016/S0883-2927(00)00082-2

[7] Arukwe, A., Eggen, T. and Möder, M. (2012) Solid Waste Deposits as a Significant Source of Contaminants of Emerging Concern to the Aquatic and Terrestrial Environments-A Developing Country Case Study from Owerri, Nigeria. Science of the Total Environment, 438, 94-102. https://doi.org/10.1016/j.scitotenv.2012.08.039

[8] Assmuth, T.W. and Strandberg, T. (1993) Groundwater Contamination at Finnish Landfills. Water Air and Soil Pollution, 69, 179-199.

[9] Eggen, T., Möder, M. and Arukwe, A. (2010) Municipal Landfill Leachates: A Signification Source for New and Emerging Pollutants. Science of the Total Environment, 408, 5147-5157. https://doi.org/10.1016/j.scitotenv.2010.07.049

[10] Ikem, A., Osibanjo, O., Sridhar, M.K.C. and Sobande, A. (2002) Evaluation of Groundwater Quality Characteristics near Two Waste Sites in Ibadan and Lagos, Nigeria. Water, Air, and Soil Pollution, 140, 307-333.

[11] Talalaj, I.A. (2014) Assessment of Groundwater Quality near the Landfill Site using the Modified Water Qualityindex. Environmental and Monitoring Assessment, 186, 3673-3683. https://doi.org/10.1007/s10661-014-3649-1

[12] Luciana, F.D.O. and Claudia, B.D.R.M. (2014) Chromium Accumulation in the Asian Clam, Corbicula fluminea (Muller, 1774), as an Indicative of Landfill Leachate Contamination. Bulletin of Environmental Contamination and Toxicology, 93, 149-153. https://doi.org/10.1007/s00128-014-1313-7

[13] Mor, S., Ravindra, K., Dahiva, R.P. and Chandra, A. (2006) Leachate Characterization and Assessment of Groundwater Pollution near Municipal Solid Waste Landfill Site. Environmental and Monitoring Assessment, 118, 435-456.

http://hdl.handle.net/2299/2039 https://doi.org/10.1007/s10661-006-1505-7

[14] Fekri, A., Wahbi, M., Ben Bouzian, A., Souabi, S. and Marrakchi, M. (2004) Etat de la qualité des eaux souterraines en aval de la décharge de Mediouna (Casablanca Maroc). The 1 st International Symposium on the Management of Liquid and Solid Residus (MALISORE), Mohammedia, 26 - 27 2004, 371.

[15] Kanmani, S. and Gandhimathi, R. (2013) Investigation of Physicochemical Characteristics and Heavy Metal Distribution Profile in Groundwater System around the Open Dump. Applied Water Science, 3, 387-399. https://doi.org/10.1007/s13201-013-0089-y

[16] Dzifa, D., Akiti, T.T., Osae, S., Tutu, A.O., Blankson, S., Ayivor, J.E., Adu-Kwame, F.N. and Egbi, C. (2012) Leachate Characterization and Assessment of Unsatured Zone Pollution near Municipal Solid Waste Landfill Site at Oblogo, Accra-Ghana. Research Journal of Environmental Earth Science, 4, 134-141.

[17] Amadi, A.N. and Nawakwoala, H.O. (2013) Evaluation of Heavy Metal in Soil from Nyimba Dumpsite in Aba, Southeastern Nigeria using Contamination Factor and Geo-Accumulation Index. Energy and Environment Research, 3, 125-134.

[18] Lejon, D.P.H., Martins, J.M.F., Lévêque, J., Spadini, L., Pascault, N., Landry, D., Milloux, M.J., Nowak, V., Chaussod, R. and Ranjard, L. (2008) Copper Dynamics and Impact on Microbial Communities in Soils of Variable Organic Status. Environmental Science and Technology, 42, 2819-2825. https://doi.org/10.1021/es071652r

[19] Long, Y.Y., Hu, L.F., Fang, C.R., Wu, Y.Y. and Shen, D.S. (2009) An Evaluation of 
the Modified BCR Sequential Extraction Procedure to Assess the Potential Mobility of Copper and Zinc in MSW. Microchemical Journal, 91, 1-5. https://doi.org/10.1016/j.microc.2008.05.006

[20] Maksymiec, W. (1997) Effect of Copper on Cellular Processes in Higher Plants. Photosynthetica, 34, 321-342. https://doi.org/10.1023/A:1006818815528

[21] Prechthai, T., Parkpian, P. and Visvanathan, C. (2008) Assessment of Trace Metal Contamination and Its Mobilization from Municipal Solid Waste Open Dumping Site. Journal of Hazardous Materials, 156, 86-94. https://doi.org/10.1016/j.jhazmat.2007.11.119

[22] Smith, D.C., Sacks, J. and Senior, E. (1999) Irrigation of Soil with Synthetic Landfill Leachate-Speciation and Distribution of Selected Pollutants. Environmental Pollution, 106, 429-441. https://doi.org/10.1016/S0269-7491(99)00094-9

[23] Zaafour, M.D. (2012) Impact des déchrages sauvages sur les zones humides de la région d'El-Tarf (Algérie) Magister dans le cadre de l'école doctorale écologie et environnement. Université Badji-Mocktar Annaba, Annaba, 166 p.

[24] Ritter, L., Solomon, K., Sibley, P., Hall, K., Keen, P., Mattu, M. and Linton, B. (2002) Sources, Pathways, and Relative Risks of Contaminants in Surface Water and Groundwater: A Perspective Prepared for the Walkerton Inquiry. Journal of Toxicology and Environmental Health, Part A, 65, 1-142. https://doi.org/10.1080/152873902753338572

[25] Mushtaq, H. and Tvd Prasad, R. (2014) Toxic Trace Element Contamination in Ground Water of Bollaram and Patancheru, Andhra Pradesh, India. American Journal of Chemistry, 4, 1-9.

[26] Li, J., Li, F., Liu, Q. and Zhang, Y. (2014) Trace Metal in Surface Water and Groundwater and Its Transfer in a Yellow River Alluvial Fan: Evidence from Isotopes and Hydrochemistry. Science of the Total Environment, 472, 979-988. https://doi.org/10.1016/j.scitotenv.2013.11.120

[27] Mansouri, B., Salehi, J. and Rezaei, M. (2014) Leachate and Pollution Levels of Heavy Metals in the Groundwater near Municipal Solid Waste Landfill Site of Mashhad, Iran. Iranian Journal of Toxicology, 8, 1068-1072.

[28] Adjiri, O.A., Gone, D.L., Kouame, I.K., Kamagate, B. and Biemi, J. (2008) Caractérisation de la pollution chimique et microbiologique de l'environnement de la décharge d'Akouedo Abidjan-Côte d'Ivoire. International Journal of Biological and Chemical Sciences, 2, 401-410.

[29] Kouassi, A.E., Ahoussi, K.E., Koffi, Y.B., Kouame, I.K., Soro, N. and Biemi, J. (2014) Caractérisation physico-chimique du lixiviat d'une décharge de l'Afrique de l'ouest: Cas de la décharge d'Akouédo (Abidjan-Côte d'Ivoire). Larhyss Journal, 19, 63-74.

[30] Adjiri, O.A., Goné, D.L., Soro, N., Kouamé, K.V. and Biémi, J. (2014) Caractérisation du biogaz de la décharge d'Akouédo (Abidjan, Côte d'Ivoire): Influence des saisons sur le potentiel d'émanation naturelle. Pollution atmosphérique, 223, 1-11.

[31] Kouame, I.K., Dibi, B., Koffi, K., Savane, I. and Sandu, I. (2010) Statistical Approach of Assessing Horizontal Mobility of Heavy in the Soil of Akouedo Landfill Nearby Ebrie Lagoon (Abidjan-Cote d'Ivoire). International Journal of Conservation Science, 1, 149-160.

[32] Kouadio, G., Dongui, B. and Trokourey, A. (2000) Détermination de la pollution chimique des eaux de la zone de la décharge d'Akouédo-Abidjan, (Côte d'Ivoire). Revue des Sciences et Techniques, 1, 33-41.

[33] Kouame, K.I. (2007) Pollution Physico-Chimique des eaux dans la zone de la 
décharge d'Akouedo et analyse du risque de contamination de la nappe d'Abidjan par un modèle de simulation des écoulements et du transport des polluants. Thèse de Doctorat, Université d'Abobo Adjamé, Côte d'Ivoire, 212 p.

[34] El Khamlichi, M.A., Lakrabni, S., Kabbaj, M., Jarby, E. and Kouhenm (1997) Etude d'impact de la décharge d'Akrach (Rabat, Maroc) sur la qualité des ressources en eau. Revue Marocaine Civil, 68, 17-31.

[35] Tränkler, J., Visvanathan, C., Kuruparan, P. and Tubtimthai, O. (2005) Influence of Tropical Seasonal Variations on Landfill Leachate Characteristics-Results from Lysimeter Studies. Waste Management, 25, 1013-1020.

https://doi.org/10.1016/j.wasman.2005.05.004

[36] Bahaa-eldin, E.A.R., Yusoff, I., Samsudin, A.R., Yaacob, W.Z.W. and Rafek, A.G.M. (2010) Deterioration of Groundwater Quality in the Vicinity of an Active Open-Tipping Site in West Malaysia. Hydrogeology Journal, 18, 997-1006. https://doi.org/10.1007/s10040-009-0567-3

[37] Tchobanoglous, G., Theisen, H. and Vigil, S. (1993) Integrated Solid Waste Management. McGraw-Hill International Edition, New York, 978 p.

[38] Kjeldsen, P., Barlaz, M.A., Rooker, A.P., Baun, A., Ledin, A. and Christensen, T.H. (2002) Present and Long-Term Composition of MSW Landfill Leachate: A Review. Critical Reviews in Environmental Science and Technology, 32, 297-336. https://doi.org/10.1080/10643380290813462

[39] Er-Raioui, H., Bouzid, S., Khannous, S. and Zouag, M.A. (2011) Contamination des eaux souterraines par le lixiviat des décharges publiques: Cas de la nappe phréatique R'Mel (Province de Larache-Maroc Nord-Occidental). International Journal of Biological Chemical Science, 5, 1118-1134.

[40] Olivero-Verbel, J., Padilla-Bottet, C. and De la Rosa, O. (2008) Relationships between Physicochemical Parameters and the Toxicity of Leachates from Municipal Solid Waste Landfill. Ecotoxicology Environmental Safe, 70, 294-299. https://doi.org/10.1016/j.ecoenv.2007.05.016

[41] Chofqi, A., Abdekader, Y., Elkbri, L., Jacky, M. and Alain, V. (2004) Environmental Impact of an Urban Landfill on a Costal Aquifer (El Jadida, Morocco). Journal of African Earth Science, 39, 509-516. https://doi.org/10.1016/j.jafrearsci.2004.07.013

[42] WHO (World Health Organization) (2003) Copper in Drinking-Water. Background Document for Preparation of WHO Guidelines for Drinking-Water Quality, Geneva, 1-23.

[43] Chu, L.M., Cheung, K.C. and Wong, M.H. (1994) Variations in the Chemical Properties of Landfill Leachate. Environmental Management, 18, 105-117. https://doi.org/10.1007/BF02393753

[44] Legret, M. (1993) Speciation and Mobility of Heavy Metals in a Simulated Landfill. International Conference Heavy Metals in the Environment, Toronto, 12-17 September 1993, Vol. 2, 463-466.

[45] Moturi, M.C.Z., Rawat, M. and Subramanian, V. (2004) Distribution and Fractionation of Heavy Metals in Solid Waste from Selected Sites in the Industrial Belt of Delhi, India. Environmental Monitoring Assessment, 95, 183-199. https://doi.org/10.1023/B:EMAS.0000029900.86810.85

[46] Mor, S., Ravindra, K., Vischher, A., Dahiya, R.P. and Chandra, A. (2006) Municipal Solid Waste Characterisation and Its Assessment for Potential Methane Generation at Gazipur Landfill Site, Delhi: Case Study. Science of Total Environment, 371, 1-10. https://doi.org/10.1016/j.scitotenv.2006.04.014

[47] Del Fava, J. (1992) Spéciation des métaux lourds dans les ordures ménagères et leur 
produit de traitement par digestion anaérobie. Thèse de doctorat, Université de Montpellier II.

[48] Baccini, P., Henseler, G., Figi, R. and Belevi, H. (1987) Water and Element Balances of Municipal Solid Waste Landfills. Waste Management and Research, 5, 483-499. https://doi.org/10.1177/0734242X8700500162

[49] Martensson, A.M., Aulin, C., Wahlberg, O. and Agren, S. (1999) Effect of Humic Substances on the Mobility of Toxic Metals in a Mature Landfill. Waste Management and Research, 17, 296-304. https://doi.org/10.1177/0734242X9901700406

[50] François, V. (2004) Détermination d'indicateurs d'accélération et de stabilisation de déchets ménagers enfouis. Etude de la recirculation de lixiviats sur colonnes de déchets. Thèse de doctorat, Université de Limoges, Limoges, 186.

[51] Ohwoghere, A.O. and Aweto, K.E. (2013) Leachate Characterization and Assessment of Groundwater and Surface Water Qualities near Municipal Solid Waste Dump Dite in Effurun, Delta State, Nigeria. Journal of Environment and Earth Science, 3, 126-134.

[52] Al Sabahi, E., Abdul Rahim, S., Wan Zuhairi, W.Y., Fadhl Al, N. and Fares, A. (2009) The Characteristics of Leachate and Groundwater Pollution at Municipal Solid Waste Landfill of Ibb City, Yemen. American Journal of Environmental Sciences, 5, 256-266. https://doi.org/10.3844/ajessp.2009.256.266

[53] Yoshida, M., Ahmed, S., Nebil, S. and Ahmed, G. (2002) Characterization of Leachate from Henchir El Yahoudia Close Landfill. Water Waste Environmental Ressource, 1, 129-142.

[54] Khattabi, H. (2002) Intérêts de l'étude des paramètres hydrogéologiques et hydrobiologiques pour la compréhension du fonctionnement de la station de traitement des lixiviats de la décharge d'ordures ménagères d'Etueffont (Belfort, France). Thesis, University Franche Comte, Besançon, 171 p.

[55] Bureau of Indian Standard (BIS) (1991) Indian Standard Speciation for Drinking Water. IS 1000, 2-4.

[56] WHO (World Health Organization) (2008) Guidelines for Drinking Water Quality. Incorporating 1st and 2nd Addenda, 3rd Edition.

[57] WHO (World Health Organization) (2011) Guidelines for Drinking Water Quality. 4th Edition, Vol. 1, Geneva.

[58] United State EPA (2009) Edition of the Drinking Water Regulations and Health Advisories. EPA 822-R-09-011 Office of Water.

[59] Union European (1998) Council Directive 98/83/EC of 3 Nov. 1998 on the Quality of Water Intended for Human Consumption.

[60] El Kharmouz, M., Sbaa, M., Chafi, A. and Saadi, S. (2013) Décharge publique de la ville d'Oujda (Maroc Oriental) sur la qualité physicochimique des eaux souterraines et superficielles.

[61] Byragi Reddy, T., Venkata Ramana, Ch., Bhaskar, Ch. and Jagadeesh Chandrababu, P. (2012) Assessment of Heavy Metal Study on Ground Water in and around Kapuluppada MSW Site, Visakhapatnam AP. International Journal of Science and Nature, 3, 468-471.

[62] Issola, Y., Kouassi, A.M., Dongui, B.K. and Biemi, J. (2008) Caractéristiques physico-chimiques d'une lagune côtière tropicale: Lagune de Fresco (Côte d'Ivoire). Afrique Science, 4, 368-393.

[63] Kouassi, A.M., Tidou, A.S. and Kamenan, A. (2005) Hydrochemical Characteristics 
of the Waters of a Eutrophic Tropical Lagoon (the Ebrie lagoon, Cote d'Ivoire) Part I: Seasonal Variation of the Hydrochemical Parameters. Agronomie africaine, 17, 117-136.

[64] Durfour, P. (1982) Les frontières naturelles et humaines du système lagunaire Ebrié. Incidences sur l'hydroclimat. Hydrobiologia, 94, 105-120.

https://doi.org/10.1007/BF00010889

[65] Dufour, P. and Slepoukha, M. (1975) L'oxygène dissous en lagune Ebrié: Influence de l'hydroclimat et la pollution. Document Scientifique Centre Recherche Océanographique. Abidjan, 6, 75-118.

[66] Adama, D.T., Métongo, S.B., Trokourey, A. and Brokra, Y. (2012) Assessment of Waters Contamination by Nutriments and Heavy Metals in Ebrié Lagoon (Abidjan, Ivoiry Coast). Research Journal of Environmental Toxicology, 6, 198-209. https://doi.org/10.3923/rjet.2012.198.209

[67] Tay, C.K., Asmah, R. and Biney, C.A. (2009) Trace Metal Levels in Water and Sediment from the Sakumo II and Muni 330 Lagoons, Ghana. West African Journal of Applied Ecology, 16, 75-94.

[68] Obasohan, E.E., Oronsaye, J.A.O. and Eguavoen, O.L. (2007) Determination of Post Dredging Concentration of Selected Trace Metal in Water, Sediment and Freshwater Mudfish (Clarias gariepunus) from Ikpoba in Benin City, Edo City Nigeria. African Journal of Biotechnology, 6, 470-474. http://www.academicjournals.org/AJB

[69] Ochieng, E.Z., Lalal, J.O. and Wandiga, S.O. (2007) Analysis of Heavy Metal in Water and Surface Sediment in Five Rift Valleys Lakes in Kenya for Assessment of Recent Increase in Anthropogenic Activities. Bulletin of Environmental Toxicology, 79, 570-576. https://doi.org/10.1007/s00128-007-9286-4

[70] Inza, B., Marcellin, Y.K., Etchian, O.A., Metongo, S.B., Trokourey, A. and Bokra, Y. (2015) Physical and Chemical Parameters and Trace Metal Concentrations in the Ebrie Lagoon 296 (Côte d'Ivoire): Influence of Tides and Urban Wastewaters. Journal of Materials and Environmental Science, 6, 1321-1329. 